\title{
The Management as a Function on Tourism Development in Kosova
}

\author{
Husnija Bibuljica
}

Associate Professor at University "Haxhi Zeka"

Doi:10.5901/ajis.2014.v3n2p165

\section{Introduction}

Management is a process that achieves one or more persons, and consists in coordination on the activities of others in order to achieve the results that one person can not accomplish alone. Management is the process of designing and maintaining environment in which individuals working in groups, efficiently achieve desired outcomes. It is characterized by the process of keeping and directing all parts of the organization, the most common business through the development and manipulation of resources (human, financial, material, intellectual and intangible.

Koontz I Weihrich define management as the process of forming and maintaining the environment in which individuals, working together in groups, efficiently achieve the selected goals. Hellrieg / Slocum give a definition according to which management achieve something committed by other persond.Kreitner define management as the process of working with each other and with others to achieve organizational goals in a changing environment with effective and efficient use of the limited resource.Menagement activity is focused on the achievement of certain advance the goals of activities of other people. The basic functions of management are leadership and control. Management is the process of directing behavior of others toward accomplishing a specific task.

\section{Tourism Management}

To give the true picture of the tourism industry it is important to say the following: wide range of sectors in the tourism industry, including transport, accommodation and attractions, dominated by private and small companies. Tourism Management is defined as the management in general, but with the use of the tourism business: management is the process of planning, organizing, hiring, management control and the evaluation of human, financial and physical resources to achieve organizational goals

The management of tourism is defined in the literature, and strategic management in tourism a well elaborated. It can be said that the management of tourism teamwork organized within certain structures and hierarchies where everyone works for the common interests, and they are the realization of the interests and needs of management (profit and growth), employees (meeting the financial needs and development), tourists (or users of services and products) that are the result of teamwork of management and employees in the tourism society (filling duction needs and wants).

With regard to development trends, natural resources, infrastructure condition, current level of development of tourism, as well as strategic focus, to develop in the future as an ecological tourist country, tourism is a long-term one of the most promising industries in Kosovo. Tourism development is determined primarily by natural and geographical characteristics and culture, along with appropriate development and engagement of human factors and quality management of tourist destinations. In terms of geography, for example, is the most important concentration of natural resources and the variety of the small geographical area (on the one hand and the attractiveness of the continental hinterland, on the other side of the cultural traditions and natural richness). 
Graph 1. The new organizational structure of the hotel

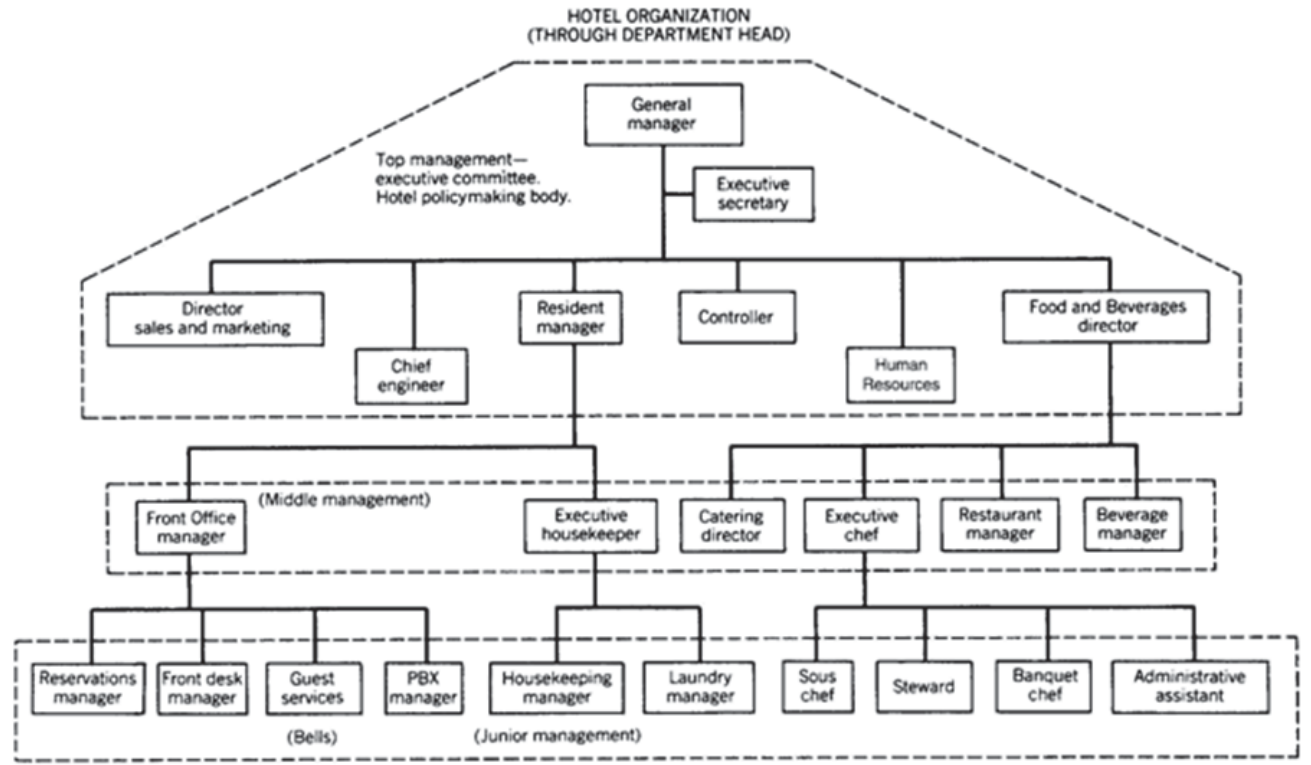

Tourism Management is a specific and very tourist (Hotel Management, Catering) activity in which combine products and services. Different people look at the system and subsystems. tourism companies differently. Employee of the Tourism Society looks at society as a system which ensures the job, as owner of the system that generates profits, and customer as a system which ensures a quality vacation. Each of these individuals invest different resources in the fulfillment of their interests that are most important to him and wants to accomplish the task management in tourism related to the planning, organization, management and control, then the control "weak " places in the hotel that are usually a result of defects governing:

- Authoritarian style of governing, the burden on routine decisions, business decisions which are not processed enough, unstructured flow of information

- Formulate clear objectives and a lack of business analysis, planning and control

- Lack of concern about the motivation of employees

- Insufficiently developed system of cost and performance (accounting) with a clear

- Showing the success or failure of each product, group of products, markets and so on.

- The lack of quality information for decision making

- Policy operations: imbalance in the department, capacity

- Rarely market research, underdeveloped system cost and output.

\section{Strategy Tourism Management}

Today tourism is rapidly exceeding the global level, there are new destinations, facilities tourism products and services of a travel company that wants to survive and succeed must meet new trends and include them in your strategy, because yesterday's requirements and needs are already out of date. The rate of change and the changes of trends carries the need for more frequent review and altering strategies and plans in order to maintain harmony with the demands of the market. Time is changing and the deployment of resources and organization of tourist services future will offer packages aimed at individual needs and problems of customers and provide them with the flexibility of planning their own holiday. It will also be reduce seasonal variations which contributes to full capacity, and hence profitability. Since the changing needs of tourists, tourism companies must adapt to these needs meaning of the strategy is to define and follow one or several strategies - a number of strategies constitutes an improper deployment of resources and confusion. The ILO strategy and be involved management who adopt and monitor its execution, and all departments of society, since it is they spend. After the strategic planning followed by quantification of business objectives through the business plan and 
then prepared, one-year plan and budget. This strategic planning process is repeated each year evaluating goals made in the previous year and setting new goals for the next period.

Graph 2. Business Productivity hotel companies through revenue and profit in Kosovo

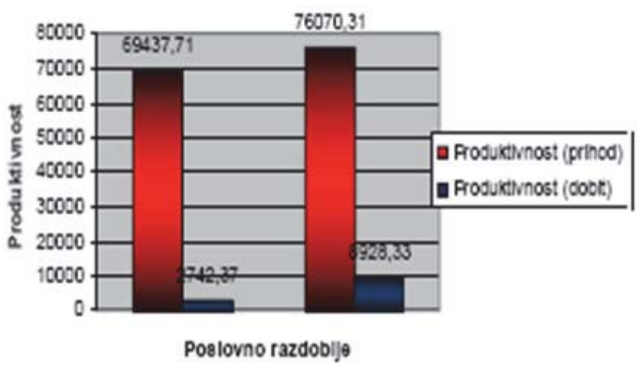

Source: Plan strategy for the development of tourism MIT / RIINVEST 2007

Employees is necessary to present the strategy and seek their suggestions on how to achieve the desired strategy, and thus the desired vision. Collecting feedback from employees has several advantages: easier implementation strategies in everyday work environment and a better quality strategies through tasks, goals and plans. Everyone, regardless of hierarchical position in society, you should understand the strategy and know how it can contribute to achieving it, because that is the purpose of strategic planning is met. To achieve this, the strategy has to be reformulated in goals that are transferred to the level of comprehensibility and applicability to everyday business departments and individual goals Inclusion of employees in strategic planning achieves the feeling of involvement in the creation of strategies, and thus the motivation and commitment of implementation strategies. available data suggest the expansion of economic activity in Kosovo, most of the municipal and in some cases nationally stage.Nature wealth of Kosovo is a great tourist resource. Description of Kosovo's tourism potential is very closely link the geographical position of Kosovo. His geographic position in south - eastern Europe, with a central position in the Balkan Peninsula, is a crossroads of the historical reach Weather Romans. Tourism constitutes 8-9 \% of GDP. Appropriate position, Kosovo, in relation to relevant full tourism center, located at the following spatial distances:

- Adriatic Sea - Albanian coast

- Pristina - Aegean Sea - Thessaloniki $340 \mathrm{~km}$

- Pristina - Belgrade $360 \mathrm{~km}$

- Pristina - Nis $138 \mathrm{~km}$

- Pristina - Sofia $290 \mathrm{~km}$

- Pristina - Skopje 84 km

- Pristina - Budva $350 \mathrm{~km}$

Consequently, tourism management must suffer the impact of globalization, that whether we like it or not is more present. The authors have different views on the tourism sector in the future. Some authors give quite pessimistic, and optimistic forecasts of tourism development in the future. However, all agree in their predictions that tourism in the future depends on the development of border areas. The size and structure of the population, economic potential, technological innovation, political and cultural trends are commonly listed factors that affect the directions of the development of tourism in the coming periodu.Budućnost tourism will depend largely on factors outside of this phenomenon, but the factors within himself. Given that there are different opinions of the authors on the key factors of tourism development in the future, in which each of its corners provides a possible development of the situation, here cite the viewpoint of the author, that I think have the most comprehensive approach. listed the following factors that influence the development of tourism:

- limit the growth of the market;

- quality, differentiation and renewal of destination;

- responsibility or social marketing;

- changes in political structures;

- changes in the distribution of tourism (especially the development of the movement from north to south).

In his work, says life cycle tourism, starting from the middle of the last century, so its possible development in the 
future. The cycle describes the characteristics of tourism historically, starting with the old diversity of tourism, which is characterized by mass tourism, a new tourism, characterized by new requirements contained in the revised requirements and expectations of tourists and their behavior. Based on the above, the author of the image lifecycle of tourism shows the following changes:

Figure 1: Life cycle tourism.

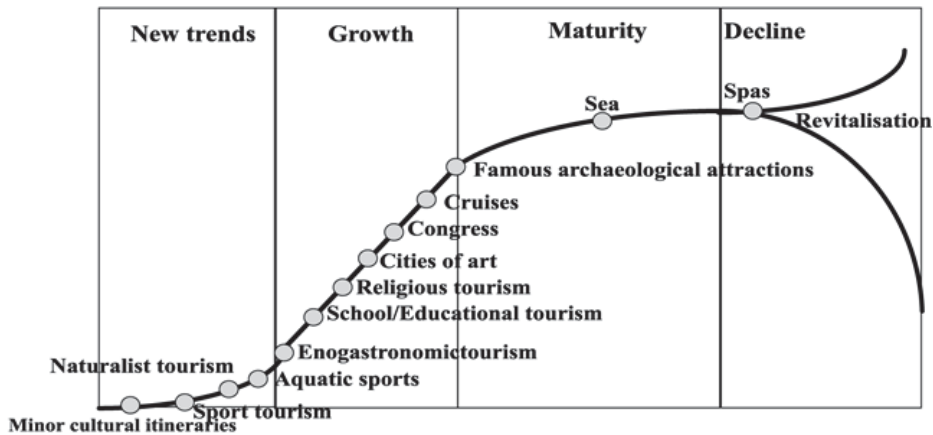

Each company are available various types of possible business strategies. In view of the tourist product, market position, the size of the investment required and the type of customers the company may choose one of the business strategy:

- Growth strategy

Company prior to the growth (prior to the development of the product and its promotion) must enter the large investments that corroborate of product development, without which there is no market penetration. During the growth stage companies and investment returns. This strategy applies if the company has a strong position in the fast growing market. The Company may decide to solidify a position in the tourism market, buy one or more competitors and diversify in order to get closer to the customer vertical integration.

- The strategy of spreading

Selecting growth strategy the company may choose: deeper penetration into existing tourist market development of a new market of its own, the direction of product development and how to diversify tourism products.

- The strategy of market penetration

The Company uses this strategy when selling already existing tourism product already existing market. For such a strategy is to develop techniques to increase sales: Privatesales of tourism products (higher content, increased use of) existing customers, or may opt for a strategy of market expansion - more customers in existing markets buy coach product.

- Strategy for development of the tourism market

This is about the development of the market by finding new ways of using existing products or selling existing products to new customers. Thus, the same tourism products coming to new customers.

- The strategy of product development

How to society other interesting same market, this strategy involves changing the tourism product - or it increases quality and is sold in larger quantity to price increases. This leads to two important modifications where, in both cases increasing the value of tourist products for existing customers.

- Diversification strategy

The Company 's strategy seeks to create new tourism products for new customers. This strategy is applicable when the Company believes that there is a market that provides opportunity for growth, where the risk can be arranged in multiple markets and when we want to equalize seasonal and Out of season sales of tourism products.

\section{Conclusion}

The paper sought to elaborate generally applicable model for improving business processes of introduction, quality and 
application of information systems in business processes, in terms of better management and improved business analysis of the current situation, defining goals and plans for the future period, the prerequisites for achieving these goals (among other things, rationalization, re-engineering, motivating employees) and analysis. Companies do not know where it is now in relation to the market, where it wants to reach, do not fully exploit the potential, there are not enough good organization, hierarchy and accountability, no business plans, problems are solved instantly, poor, and employees are not motivated, and time of maximum productive. All companies (here focusing on tourism) must define your business goals, mission, vision and strategy. Model continuous improvement of business processes that helps the inclusion of these elements in future goals and plans, monitor and measure their achievement Controlling help management in planning, budgeting, analysis of operating results and plans, improving information systems, organization of business processes, working with human resource development various analyzes and reports that simulate the results of alternative business decisions and constant monitoring of operations indicate anomalies soon after their formation. This enables immediate response and resolution to the company's operations again back on the path to the goal. The function of controlling the better performance management which includes better information, better reporting, better information flow, better business processes and improved basis for decision-making also, what is Kosovo's hotel industry needs now is the collection and analysis of data on the results of operations of the Kosovo hospitality. By comparing the Kosovo hotel with competitive foreign tourist countries would receive the true picture of the strengths and weaknesses and the quality of business decisions, and to promote the strength of Kosovo hospitality and address weaknesses get a competitive edge.

\section{References}

Abell, D. F., Hammond, J. S.: Strategic market planning: problems and analytical approaches Prentice-Hall, New Jersey, SAD, 1979

Avelini Holjevac, I.: Kontroling - upravljanje poslovnim rezultatom, Hotelijerski fakultet, Opatija, 1998

Avelini Holjevac, I Quality management in tourism and hospitality industry 16th Biennial International Congress, Hotel \& Tourism 2002., Faculty of Tourism and Hospitality Management, Opatija

Buble, M. i dr Strateški menadžment Sinergija, Zagreb, 2005

Dulcic, A.: Turizam: nacela razvoja i praksa, Zagreb, Institut za turizam, 1991

Moutinho, L. i suradnici (prijevod Duško Cavic): Strateški menadžment u turizmu Zagreb, Masmedia, 2005.

\section{Other sources}

Azra,http://www.azra.hr/documents/8\%20\%20smjernice\%20razvoja\%20turizma.pptđ

Controllerakademie - http://www.controllerakademie.de/retraining/stufenueber/umfrage_berichtswesen_zi.p df

Izveštaj ranog upozoravanja RIINVEST 2007 Priština.

Razvoj u turizmu RIINVEST I MIT 2006 Priština. 
